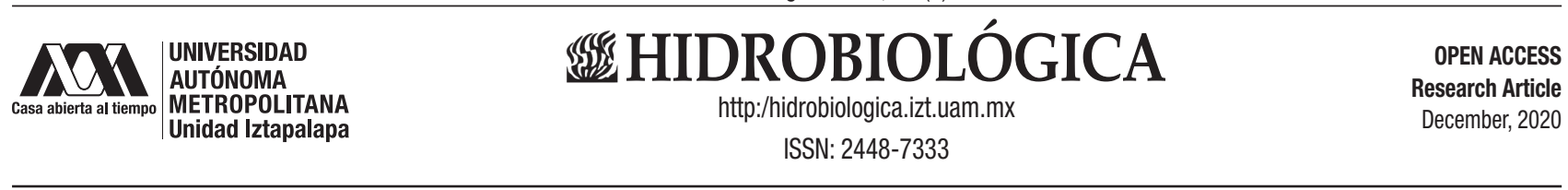

\title{
Determination of hydraulic transmissivity in coastal aquifer by optimal estimation of the Qe-T relationship using Kalman filter
}

\section{Determinación de la transmisibilidad hidráulica en un acuffero costero mediante estimación óptima de la relación Qe-T usando el filtro de Kalman}

\author{
Jaime Herrera-Barrientos ${ }^{1 \oplus}$, Héctor José Peinado-Guevara ${ }^{2 *}$, José de Jesús Campos-Gaxiola ${ }^{3}$, Adriana Cruz-Enriquez ${ }^{3}$, Víctor Manuel \\ Peinado-Guevara ${ }^{2}$, María de los Ángeles Ladrón de Guevara-Torres ${ }^{4}$, Salvador Isidro Belmonte-Jiménez ${ }^{4}$ and Leonardo Herrera ${ }^{1}$
}

\begin{abstract}
Centro de Investigación Científica y de Educación Superior de Ensenada, B.C. Carretera Ensenada-Tijuana No. 3918, Zona Playitas, Ensenada, B. C., 22860. México

Escuela de Ciencias Económicas y Administrativas, Universidad Autónoma de Sinaloa. Blvd. Juan de Dios Bátiz s/n, San Joachín, Guasave, Sinaloa, 81049. México

${ }^{3}$ Facultad de Ingeniería Mochis, Universidad Autónoma de Sinaloa. Fuente de Poseidón y Ángel Flores s/n, Jiquilpan, Los Mochis, Sinaloa, 81210. México

${ }^{4}$ Instituto Politécnico Nacional, Unidad CllDIR-Oaxaca. Hornos No. 1003, Col. Noche Buena, Municipio de Santa Cruz Xoxocot-

Background: The knowledge on the management of water as a vital resource to develop agriculture allows having greater effectiveness in its use. Goals: The agricultural activity in the lower part of the Sinaloa River depends on the fresh water of the regional dams and the aquifer. Methods: The use of groundwater represents approximately $15 \%$ of the total water used. In the presence of prolonged periods of drought, new wells are drilled without the use of an appropriate guide for farmers on the location of aquifer areas with a greater hydraulic transmissivity with the purpose of exploiting them more rationally. The National Water Commission has registered more than 680 wells on both banks of the Sinaloa River. Results: The information of 205 of these pumping wells for agricultural or domestic use and the specific capacity information was analyzed. Then, 79 out of 205 wells have pumping tests. It is then determined that the objective of this research work was to find the relationship between the specific capacity $(Q e)$ and hydraulic transmissivity $(T)$ data of the study area using the Thiem formula, considering a fixed value of the radius of influence. This hypothetical consideration and the heterogeneities of the aquifer environment add to the T-Qe relationship an additional component, it is determined that it has a normal behavior. Using the Kalman filter it is possible to eliminate or reduce such a component, thus improving the determination of the T-Qe relation of an R-value of 0.95 (without filter) to 0.97 (with filter), for a linear and exponential relationship. Conclusions: The application of a T-Qe estimate allows characterizing the aquifer area, with this procedure a map was obtained on the distribution of T, which will serve as a guide for future exploitations of groundwater in the study area.
\end{abstract} lán. Oaxaca, Oaxaca, 71230. México

*Corresponding author:

José Peinado-Guevara: e-mail:

Hpeinado75@hotmail.com

\section{To quote as:}

Herrera-Barrientos, J., H. J. Peinado-Guevara, J. de J. Campos-Gaxiola, A. Cruz-Enriquez, V. M. Peinado-Guevara, M. de los Á. Ladrón de Guevara-Torres, S. I. Belmonte-Jiménez \& L. E. Herrera. 2020. Determination of hydraulic transmissivity in coastal aquifer by optimal estimation of the Qe-T relationship using Kalman filter. Hidrobiológica 30 (3): 211-219.

DOl:10.24275/uam/izt/dcbs/hidro/2020v30n3/ Herrera
Keywords: groundwater, hydraulic parameters, Kalman filter, Thiem formula

\section{RESUMEN}

Antecedentes: El conocimiento sobre el manejo del agua como recurso indispensable para desarrollar la agricultura permite tener mayor efectividad en su uso. Objetivos: La actividad agrícola en la parte baja del río Sinaloa depende del agua dulce de las presas regionales y del acuífero. Métodos: El uso del agua subterránea, representa aproximadamente el 15\% del agua total usada. Ante la aparición de periodos de sequía prolongados, se perforan nuevos pozos sin el uso de una guía apropiada que oriente a los agricultores sobre la ubicación de las zonas acuíferas que tienen una mayor transmisividad hidráulica con el propósito de explotarlos de manera más racional. Resultados: La Comisión Nacional del agua tiene registrados más de 680 pozos en ambas márgenes del Río Sinaloa. Se analizó la información de 205 de estos pozos de bombeo para uso agrícola o doméstico y la información de capacidad específica. De este número, 79 pozos tienen pruebas de bombeo. Se determina entonces que el objetivo de este trabajo de investigación fue encontrar la relación entre los datos de capacidad especifica $\left(Q_{\mathrm{e}}\right)$ y transmisividad hidráulica $(T)$ de la zona de estudio usando la fórmula de Thiem, considerando un valor fijo del radio de influencia. Conclusiones: Esta consideración hipotética y las heterogeneidades del medio acuífero suman a la relación $T-Q_{e}$ una componente adicional, se determina que tiene un comportamiento normal. Mediante el filtro de Kalman es posible eliminar o reducir tal 
componente, mejorando así la determinación de la relación $\mathrm{T}-\mathrm{Q}_{\mathrm{e}}$ de un valor $r$ de 0.95 (sin filtro) a 0.97 (con filtro), para una relación lineal y exponencial. La aplicación de una estimación $\mathrm{T}-\mathrm{Q}_{\mathrm{e}}$ permite caracterizar la zona acuífera, con este procedimiento se obtuvo un mapa sobre la distribución de T, que servirá de guía para futuras explotaciones del agua subterránea en la zona de estudio.

Palabras claves: agua subterránea, filtro de Kalman, fómula de Thiem, parámetros hidráulicos

\section{INTRODUCTION}

Hydraulic conductivity and transmissivity of an aquifer constitutes essential data for groundwater exploitation management and planning (Kazakis et al., 2016). Measurements of aquifer hydraulic parameters can be measured by laboratory experiments or in situ tests; however, the former are inaccurate, and the latter is expensive and difficult (Bateni et al., 2015).

Hydraulic transmissivity (T) determines the flow of groundwater that is transmitted through a vertical strip of aquifer unit width under a hydraulic gradient unit (Palafox-Avila, 2008). This parameter is required in numerical flow modeling processes (Painter et al., 2007; Asfahani, 2016); horizontal recharge of fresh water (Cruz-Falcón et al., 2013); in the determination of the radius of influence of the descent cone of the well (Vargas, 2016) in order to determine the perimeters for the protection from contamination of the well water, and water management, among others. It is useful to estimate the groundwater resource and its integral management (Tizro et al., 2012). Its determination can be from the specific well capacities $\left(Q_{\mathrm{e}}\right)$, which is obtained from the pumping flow $Q$, static and dynamic level in a pump well once it is stabilized.

Through the Thiem's formula, assuming a fixed influence radius and that there are no load losses in the wells, using a relation between transmissivity values obtained from pumping tests and their corresponding specific capacity, dependency relations are obtained between both parameters, which can be linear or exponential (Al Farrah et al., 2013).

Determinations of $T$ in the manner indicated above have been made successfully in different geological environments (Chandra et al., 2008; Perdomo et al., 2014; Malík et al., 2015; Sanz et al., 2005; Sánchez et al., 2013). WRI Report 87-4034 (2008) states that estimates of transmissivity from specific capabilities provide values that are used to characterize transmissivity in certain local areas and may reveal trends or patterns. However, there are cases where this relation is not met due to the heterogeneity present in the aquifer, and erroneous transmissivities that do not correspond to the aquifer are obtained.

The groundwater of the coastal aquifer of the lower right and left bank of the Sinaloa River constitutes an important element of support for the development of agricultural activity in the region, since the water from local dams is insufficient to irrigate the Guasave valley, that is why the extraction of groundwater is required through wells and bored wells. Of the total water used in agriculture, groundwater accounts for 15\% and surface water 85\% (Peinado-Guevara et al., 2017).

The bed of the Sinaloa River is regulated by the Gustavo Díaz Ordaz Dam. In 2005, with the water from the dam, the left and right banks of the Sinaloa River were irrigated, 54,134 ha and 45,105 ha, respectively, corresponding to the Irrigation District No.63. Guillermo Blake Aguilar is another dam in the region, with this, 21,820 ha are cultivated. C0NAGUA (2000), using the piezometric fluctuations method, determined an overexploitation of 97.3 million $\mathrm{m}^{3}$ for October 1997 and October 1998 periods.

The National Water Commission has registered more than 680 pumping wells distributed on both banks of the Sinaloa River, of the which, 79 pumping tests are analyzed with their respective information of specific capacity $Q_{e}$ and hydraulic transitivity $T$. The Kalman filter is applied to the $Q_{\mathrm{e}}-\mathrm{T}$ relation which is widely used to estimate the state of dynamic systems, as an optimization method, as an optimizer that eliminates or reduces the normal random component that is the use that will be given in this work to remove the Gaussian noise component produced naturally by assuming that the radius of influence of the wells is constant as well as by the influence of the heterogeneities of the aquifer, which deviate from the theoretical considerations of the Thiem formula which assumes that the aquifer is confined, homogeneous, isotropic, horizontal, among other considerations.

\section{MATERIALS AND METHODS}

Description of the study area. The study area lies between the coordinates $25^{\circ} 25^{\prime} 8.36$ " and $25^{\circ} 48^{\prime} 30.04^{\prime \prime}$ north latitude and $108^{\circ} 13^{\prime} 32.64^{\prime \prime}$ to $108^{\circ} 35^{\prime} 38.65^{\prime \prime}$ west longitude (Fig. 1). The climate is very hot and warm dry with rain in summer. The average annual precipitation for the period 1986-2013 fluctuated from 300 to $400 \mathrm{~mm}$ (INEGI, 2014). The average annual temperature is of 22 to $24^{\circ}$ for the serie1986-2013 (INEGI, 2014). The soils are of alluvial origin, Cenozoic era, Quaternary period, Vertisol soils predominate $(62.55 \%$ of the surface of the municipality) (INEGI, 2009).

Wells information. 205 pumping wells for agricultural or domestic use that have specific capacity information were analyzed. Of these, 79 wells have pumping tests carried out by the National Water Commission using different techniques.

Of the wells with pumping test it was obtained that $11.4 \%$ of the T values are between medium to high $\left(100<\mathrm{T}<500 \mathrm{~m}^{2} /\right.$ day), $8.9 \%$ in high $\left(500<\mathrm{T}<1000 \mathrm{~m}^{2} /\right.$ day) and $79.7 \%$ in very high $\left(\mathrm{T}>1000 \mathrm{~m}^{2} /\right.$ day $)$ according to the classification of Villanueva \& Iglesias (1984). Those values indicate that this is a coastal aquifer with high capacity to transmit water that, in the face of a scenario of overexploitation due to its high potential to be contaminated by saline intrusion or contamination by dissolution due to the presence of evaporite bodies in the study zone.

There is information of 30 lithological columns with depths ranging between 100 and 150 meters, with four lithological sections being constructed that show the heterogeneous distribution (horizontal and vertical variations) of the aquifer materials. The wells were geolocated with a portable GPS Magallanes brand.

Qe-T relation. Al Farrah et al. 2013 uses the Thiem equation which, by setting a value of $R$ and substituting that of $r_{w}$ according to the radius of the well in question, Thiem's formula can be written as

$$
\begin{gathered}
T=\frac{1}{2 \pi} \ln \left(\frac{R}{r_{w}}\right)(Q / s) \\
T=C(Q / s) \\
T=C Q e
\end{gathered}
$$


Where: $T$ is hydraulic transmissibility $\left(\mathrm{m}^{2} /\right.$ day), $\mathrm{R}$ is the radius of influence of the pumping well $(\mathrm{m})$ and $r_{w}(m)$ is the radius of the well, $s(m)$ is the depression in the well. For a given $\mathrm{R}$ value and the corresponding radius of the well $\mathrm{r}_{\mathrm{w}}$, the term $\frac{1}{2 \pi} \ln \left(\frac{R}{r_{w}}\right)$ is a constant, $\mathrm{C}$.

Hamm et al. (2005) and Galvão et al. (2016) have established relations of the form:

$$
T=C(Q / s)^{n}
$$

The range of the exponential coefficient is in a range of 0.6 to 1.4 and is related to the lithology and the aquifer (Al Farrah et al., 2013).

With 79 pairs of $Q_{\mathrm{e}}$ values, T obtained from the National Water Commission, the $Q_{e_{-}}$T ratio was found without using the Kalman filter and using the filter. From the filtered $T-Q_{e}$ ratio, a map of equal hydraulic transmissibility was obtained, which is a guide for future drilling.
Uncertainties of Qe and T. The values of $Q$ e and T present uncertainties due to the following: un aquifer tends to present heterogeneities and anisotropy, the well does not always cross the entire aquifer formation, part of the water pumped from the well reaches reincorporated into the aquifer, the pumping flow $Q$ tends to present variations due to fluctuations in the electric current of the pumping system, the diameter of the well is finite and there is usually a head drop in the well due to the screen pipe or well face, the radius of influence is often unknown, among others factors. All these variables add uncertainties to the relationship between Qe and T expressed by Thiem equation, which establishes that it is that of a straight line that passes through the origin and that, due to the aforementioned uncertainties, it undergoes variations, so that the Kalman filter eliminates additive contributions whose behavior has a normal distribution (white noise uncertainty), thus achieving a better relationship between $Q e$ and $T$ given by the correlation coefficient.
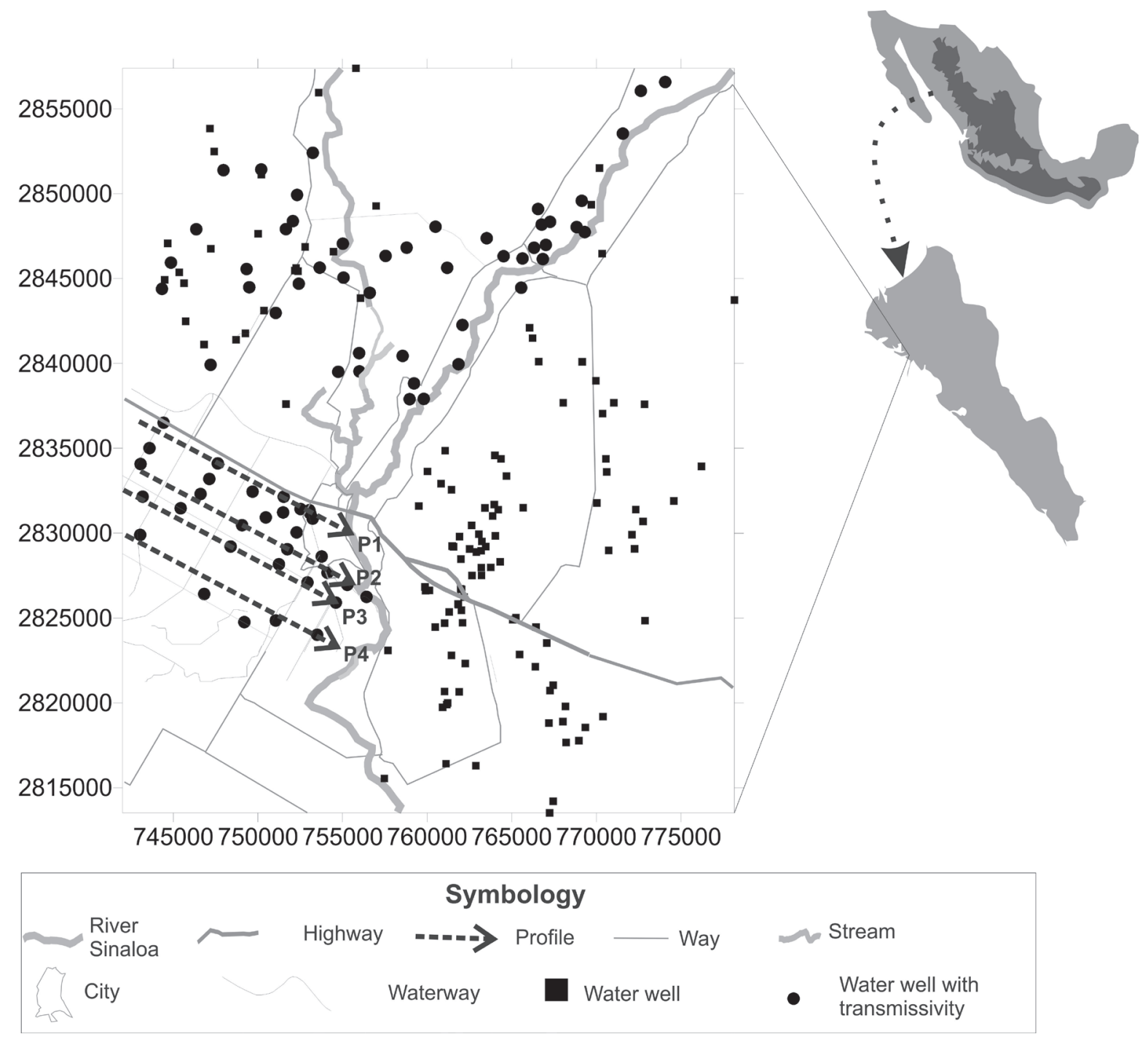

Figure 1. Location of the study area. With black circles are indicated wells with information of pumping tests and with black squares the wells with specific capacity information. 
Kalman Filter. The Kalman Filter (KF) is an optimal estimator (Kim, 2011). Faragher, 2012, indicates that it has extensive use as a noisy data smoother. Following Grewal-Mohinder \& Andrews, 1995, the discrete-time model is established for a linear stochastical system which takes the form:

$$
\begin{aligned}
& x_{k}=A_{k-1}+u_{k-1} \\
& y_{k}=C_{k} x_{k}+{ }_{k}
\end{aligned}
$$

The zero mean uncorrelated Gaussian random processes $\left\{u_{k-1}\right\}$ and $\left\{v_{k}\right\}$ have matrices of variances $Q_{k-1}$ and $R_{k}$, respectively, at time $t_{k} ; x_{k}$ describe the unknown signal; $y_{k}$ is the measurement with white gaussian noise and the matrices $A_{k-1}$ and $C_{k}$ are constants. The KF as a data softener has the form:

$$
\begin{aligned}
& \hat{x}_{k}^{-}=A_{k-1} \hat{x}_{k-1}^{+} \\
& P_{k}^{-}=A_{k-1} P_{k-1}^{+} A_{k-1}^{T}+Q_{k-1} \\
& K_{k}=P_{k}^{-} C_{k}^{T}\left(C_{k} P_{k}^{-} C_{k}^{T}+R_{k}\right)^{-1} \\
& \hat{x}_{k}^{+}=\hat{x}_{k}^{-}+K_{k}\left(y_{k}-C_{k} \hat{x}_{k}^{-}\right) \\
& P_{k}^{+}=P_{k}^{-}-K_{k} C_{k} P_{k}^{-}
\end{aligned}
$$

Where $\hat{x}_{k}$ is the estimate signal of $x_{k}$ before processing the measurement $y_{k}$ in the instant $t_{k} ; P_{k}^{-}$is the variance of the estimation error $\hat{x}_{k}^{-}$; $K_{k}$ is the optimization factor, usually named Kalman gain; $\hat{x}_{k}^{+}$describes the estimate signal of $x_{k}$ after processing the measurement $v_{k} y_{k}$ in the instant $t_{k}$; and $P_{k}^{+}$is the variance of the estimation error $\hat{x}_{k}^{+}$.

For the particular case of this work, that correspond to the filtering of signals, the system (1) and (2) as well as the KF are specified with the matrices:

$$
\begin{aligned}
& A_{k-1}=I_{2^{* 2}} \\
& C_{k}=I_{2^{*} 2}, Q_{(k-1)}=0.1 I_{2^{*} 2} R_{k}=0.01 I_{2^{*} 2} \text { and initial conditions } \\
& \hat{x}_{0}^{+}=[173,7.5]^{T} \text { and } P_{0}=I_{2^{*} 2}
\end{aligned}
$$

\section{RESULTS}

Geometry of the aquifer. With the information available from 30 lithological columns, the aquifer's geometry was determined, as well as the distribution of the aquifer materials, which, as can be seen, has significant lateral and vertical heterogeneities. Figure 2 shows four profiles with the sequence of materials showing the abundance of gravel with clay-silt matrix, highlighting the presence of a gravel body, which

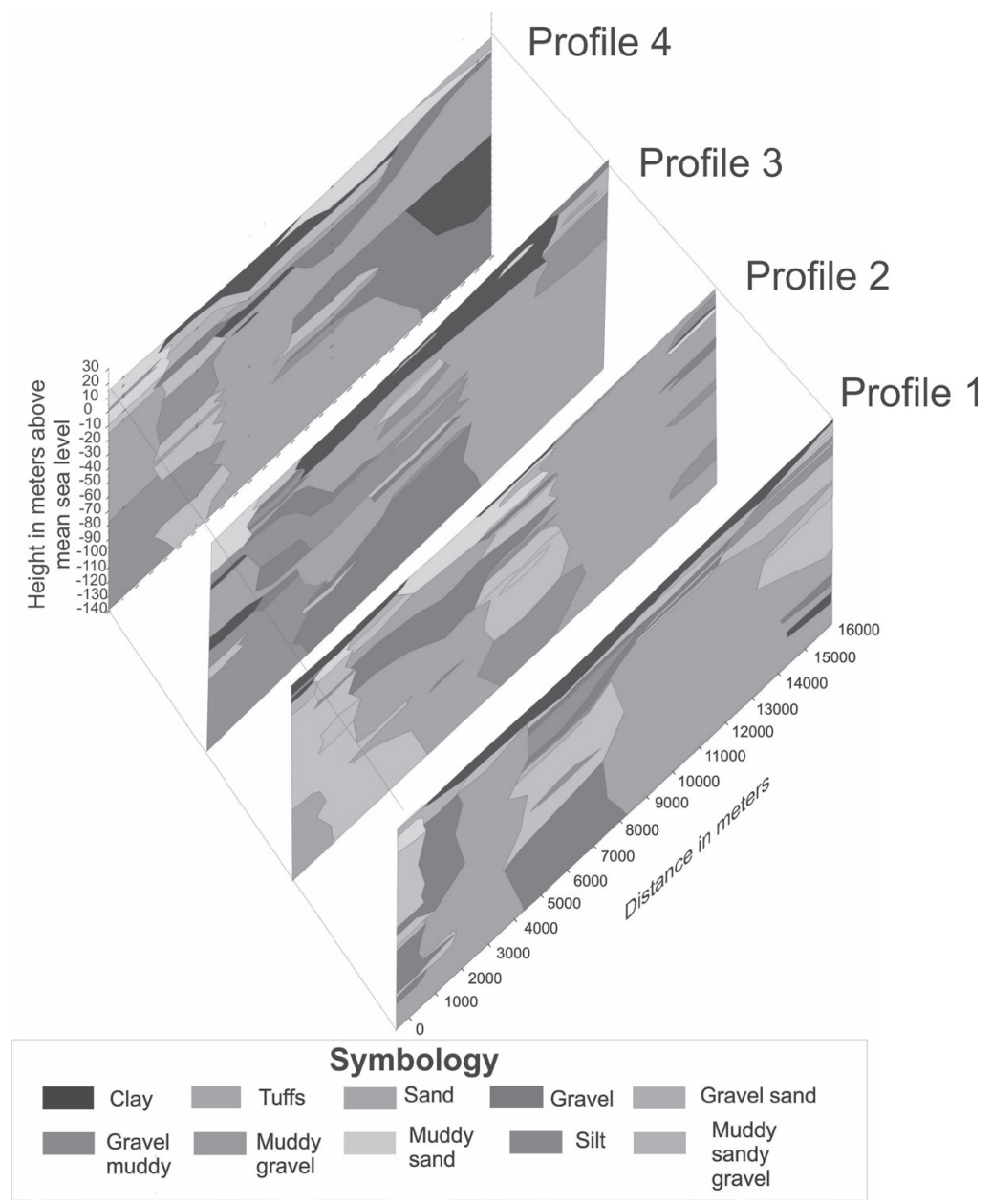

Figure 2. Perpendicular section to the Sinaloa River. 
are indicators of the ability of materials to yield water. The wells of 100 to $150 \mathrm{~m}$ partially penetrate the aquifer, since it cannot touch the geological or hydrological basement.

Relation between specific capacity and hydraulic transmissivity. The empirical approach is based on determining the empirical relations between $T$ and $Q_{\mathrm{e}}$, which are regarded as aquifer and area-specific
(El-Naqa, 1994; Al Farrah et al., 2013). Table 1 shows the values of hydraulic transmissivity, and specific capacity $Q_{\mathrm{e}}$. Figure 5 shows the relation between transmissivity and specific flow rate with an adjustment of 0.989 , so it is possible to estimate the transmissivity in function of its specific capacity. T is directly proportional to the specific flow, such as those obtained by Bosch, 2014, Chandra et al., 2008, Ebong et al., 2014 and Perdomo et al., 2014.

Table 1. Wells data from pumping tests and specific well capacities.

\begin{tabular}{|c|c|c|c|c|c|c|c|}
\hline \multicolumn{2}{|c|}{ Coordinates } & \multirow{2}{*}{$\begin{array}{c}\begin{array}{c}\text { Hydraulic } \\
\text { transmissivity }\end{array} \\
\mathrm{m} / \text { day }\end{array}$} & \multirow{2}{*}{$\begin{array}{c}\begin{array}{c}\text { Specific well } \\
\text { capacities }\left(\mathbf{Q}_{\mathrm{e}}\right)\end{array} \\
\mathrm{lps} / \mathrm{m}\end{array}$} & \multicolumn{2}{|c|}{ Coordinates } & \multirow{2}{*}{$\begin{array}{c}\begin{array}{c}\text { Hydraulic } \\
\text { transmissivity }\end{array} \\
\mathrm{m} / \mathrm{day} \\
\end{array}$} & \multirow{2}{*}{$\begin{array}{c}\begin{array}{c}\text { Specific well } \\
\text { capacities }\left(\mathbf{Q}_{\mathrm{e}}\right)\end{array} \\
\mathrm{Ips} / \mathrm{m}\end{array}$} \\
\hline $\mathrm{X}$ & $\mathrm{Y}$ & & & $\mathrm{X}$ & $\mathrm{Y}$ & & \\
\hline 749489 & 2844495 & 173 & 7.5 & 767015 & 2846992 & 3629 & 30.6 \\
\hline 750195 & 2851435 & 207 & 3.2 & 767267 & 2848352 & 3646 & 29.4 \\
\hline 758551 & 2840450 & 242 & 3.5 & 766837 & 2846157 & 4441 & 47 \\
\hline 749330 & 2845569 & 251 & 2.9 & 752315 & 2849936 & 4454 & 37 \\
\hline 744860 & 2845948 & 276 & 3.9 & 758790 & 2846828 & 4687 & 34.5 \\
\hline 759225 & 2838831 & 302 & 3.8 & 756001 & 2839538 & 4700 & 34.6 \\
\hline 747965 & 2851393 & 354 & 4.8 & 766321 & 2846824 & 5435 & 37.2 \\
\hline 766554 & 2849107 & 492 & 4.2 & 768835 & 2848045 & 6834 & 75.9 \\
\hline 763521 & 2847384 & 570 & 5 & 755058 & 2845062 & 8208 & 57.5 \\
\hline 761184 & 2845644 & 829 & 6.9 & 751056 & 2824860 & 3410 & 27.506 \\
\hline 751656 & 2847922 & 864 & 10.2 & 753500 & 2824020 & 2925 & 26.051 \\
\hline 752414 & 2844704 & 924 & 20.8 & 754605 & 2825918 & 1588 & 13.136 \\
\hline 769138 & 2849591 & 924 & 8 & 753768 & 2828632 & 1909 & 16.313 \\
\hline 764518 & 2846326 & 1020 & 8.7 & 753040 & 2831360 & 2888 & 27.334 \\
\hline 761854 & 2839960 & 1054 & 11.6 & 752519 & 2831428 & 3158 & 27.425 \\
\hline 759801 & 2837919 & 1210 & 14.5 & 751240 & 2828174 & 3116 & 25.799 \\
\hline 755019 & 2847063 & 1253 & 11.2 & 749198 & 2824766 & 4078 & 35.123 \\
\hline 744330 & 2844398 & 1305 & 11.1 & 746824 & 2826422 & 4569 & 40.408 \\
\hline 765560 & 2844468 & 1339 & 12.9 & 748387 & 2829222 & 4295 & 37.584 \\
\hline 762087 & 2842274 & 1382 & 12 & 749063 & 2830475 & 2354 & 17.067 \\
\hline 758964 & 2837902 & 1469 & 15.7 & 750466 & 2830934 & 2039 & 16.423 \\
\hline 760495 & 2848063 & 1529 & 14.2 & 751524 & 2832152 & 1695 & 14.293 \\
\hline 746357 & 2847915 & 1555 & 20.3 & 747628 & 2834115 & 1369 & 11.574 \\
\hline 755981 & 2840616 & 1555 & 17.2 & 746611 & 2832315 & 1050 & 10.214 \\
\hline 751052 & 2842985 & 1564 & 16.3 & 745434 & 2831474 & 2401 & 21.481 \\
\hline 754746 & 2839514 & 1620 & 14.2 & 756419 & 2826252 & 1721 & 14.786 \\
\hline 753243 & 2852417 & 1728 & 16.8 & 743042 & 2829906 & 2117 & 19.524 \\
\hline 756610 & 2844169 & 1771 & 18 & 743186 & 2832156 & 452 & 3.908 \\
\hline 753091 & 2831170 & 1901 & 21.5 & 743064 & 2834081 & 1676 & 14.466 \\
\hline 753236 & 2830864 & 1901 & 21.6 & 744423 & 2836516 & 987 & 10.424 \\
\hline 757544 & 2846342 & 2125 & 19 & 743590 & 2835017 & 715 & 5.937 \\
\hline 774069 & 2856590 & 2195 & 21 & 755282 & 2826961 & 1725 & 16.063 \\
\hline 772631 & 2856067 & 2316 & 22.4 & 747126 & 2833203 & 2319 & 19.399 \\
\hline 769315 & 2847747 & 2411 & 25.9 & 749683 & 2832454 & 2325 & 21.208 \\
\hline 765637 & 2846194 & 2635 & 28.1 & 751488 & 2831230 & 1254 & 11.335 \\
\hline 747203 & 2839926 & 2730 & 23.2 & 752286 & 2830051 & 2685 & 25.924 \\
\hline 766768 & 2848188 & 2981 & 29.4 & 751737 & 2829058 & 3139 & 29.707 \\
\hline 753652 & 2845651 & 3041 & 27.3 & 752929 & 2827102 & 2063 & 17.914 \\
\hline 752065 & 2848392 & 3283 & 37.4 & 754113 & 2827671 & 2207 & 18.492 \\
\hline 771567 & 2853551 & 3473 & 37.3 & & & & \\
\hline
\end{tabular}


Relation is given by:

$$
T=109.533 Q_{e}
$$

Bosch (2014) states that the factor that relates to T with $Q_{e}$ oScillates from a range between 100 to 500 , so the relation obtained is consistent with that obtained in other aquifers by other authors.

Figure 3 shows that it is possible to estimate the hydraulic transmissivity in function of specific capacity. The application of the Kalman filter to the $T-Q_{e}$ relation improved the correlation coefficient going from
0.95 to 0.97 . Figure $3 \mathrm{c}$ shows how applying the Kalman filter reduces the dispersion of the data and therefore increases $r$, as is the case.

Practical application. In 126 pumping wells $Q_{e}$ was calculated by knowing the expense, static and dynamic level of the water in each well, estimating $T$ from a relation $T=109.533 Q_{e}$. The map of equal values of hydraulic transmissivity shows that it is lower on the left bank of the Sinaloa River, which is consistent with that established by Norzagaray-Campos (2003), who built four profiles parallel to the river, indicating that the lithological changes are explained by the migration of the Sinaloa River from East to West.

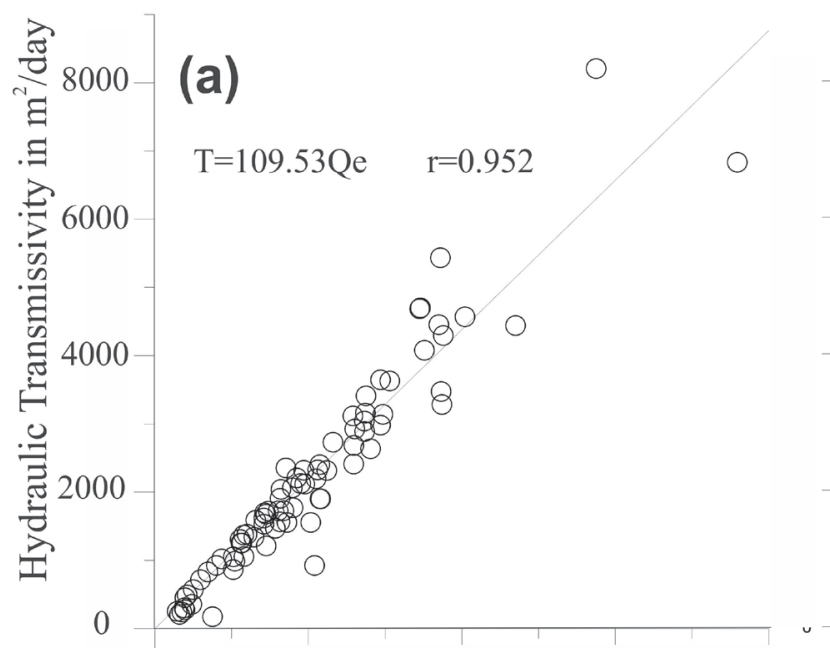

(b)
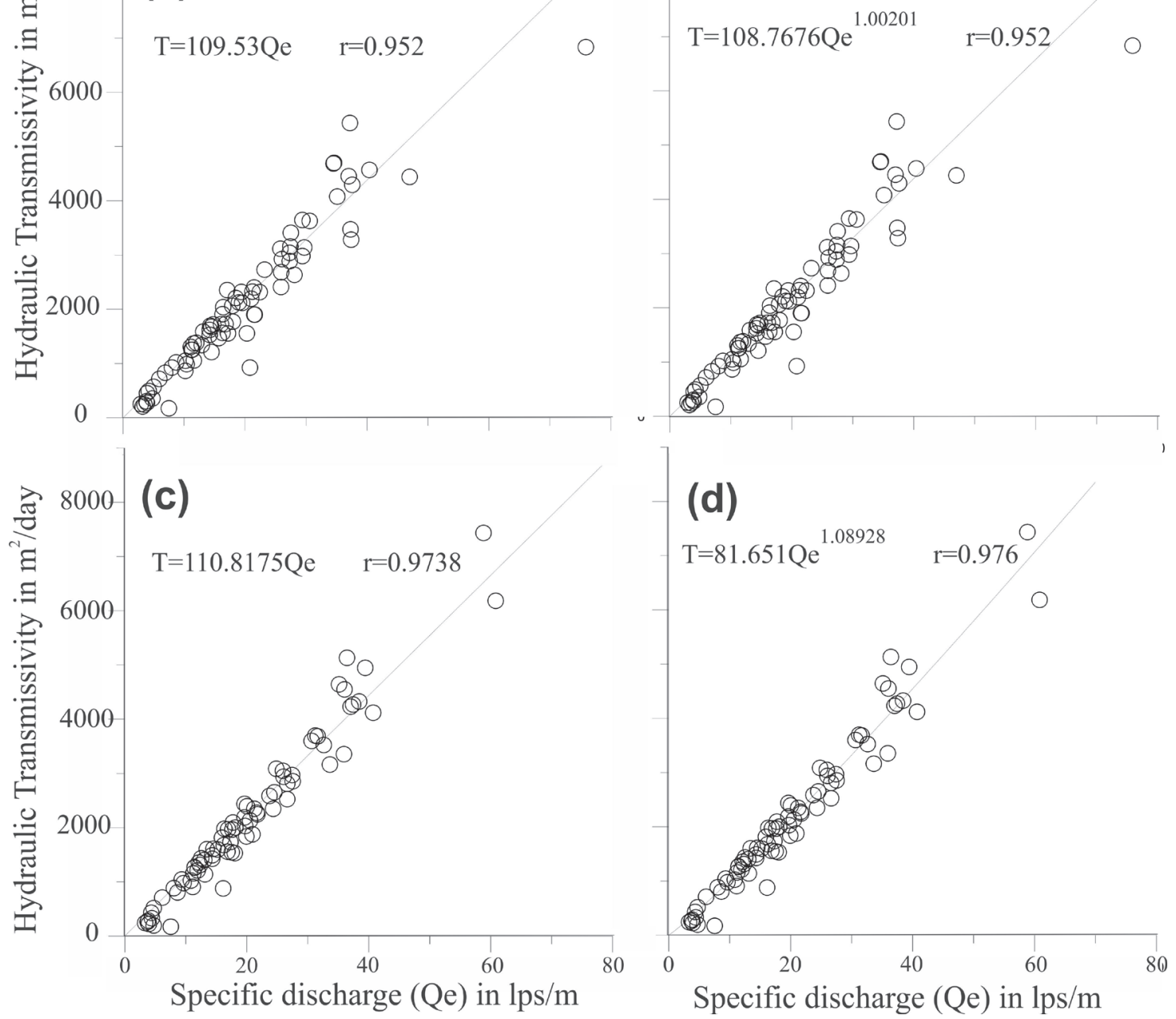

(d)

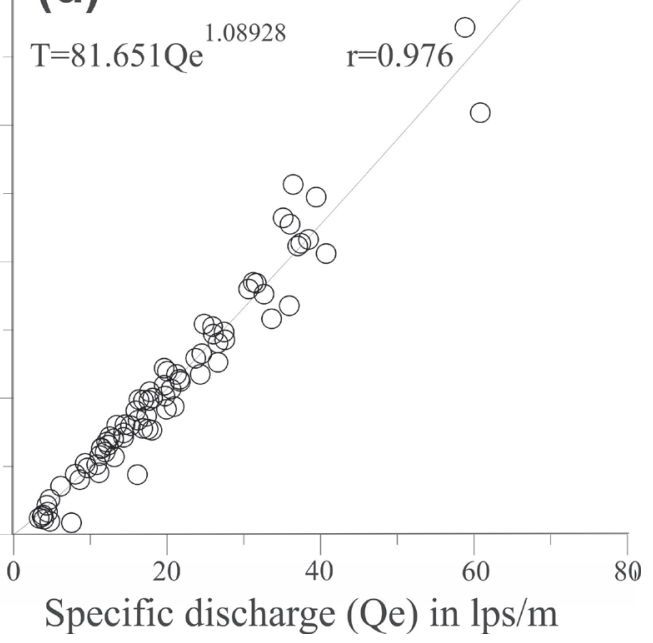

Figures 3a-d. Regression line fitting specific discharge $\left(Q_{\mathrm{e}}\right)$ and transmissivity $(\mathrm{T})$ data from pumping tests in 79 wells: a) linear regression; b) exponential relation; c) linear regression with Kalman filter; d) exponential relation with Kalman filter. 

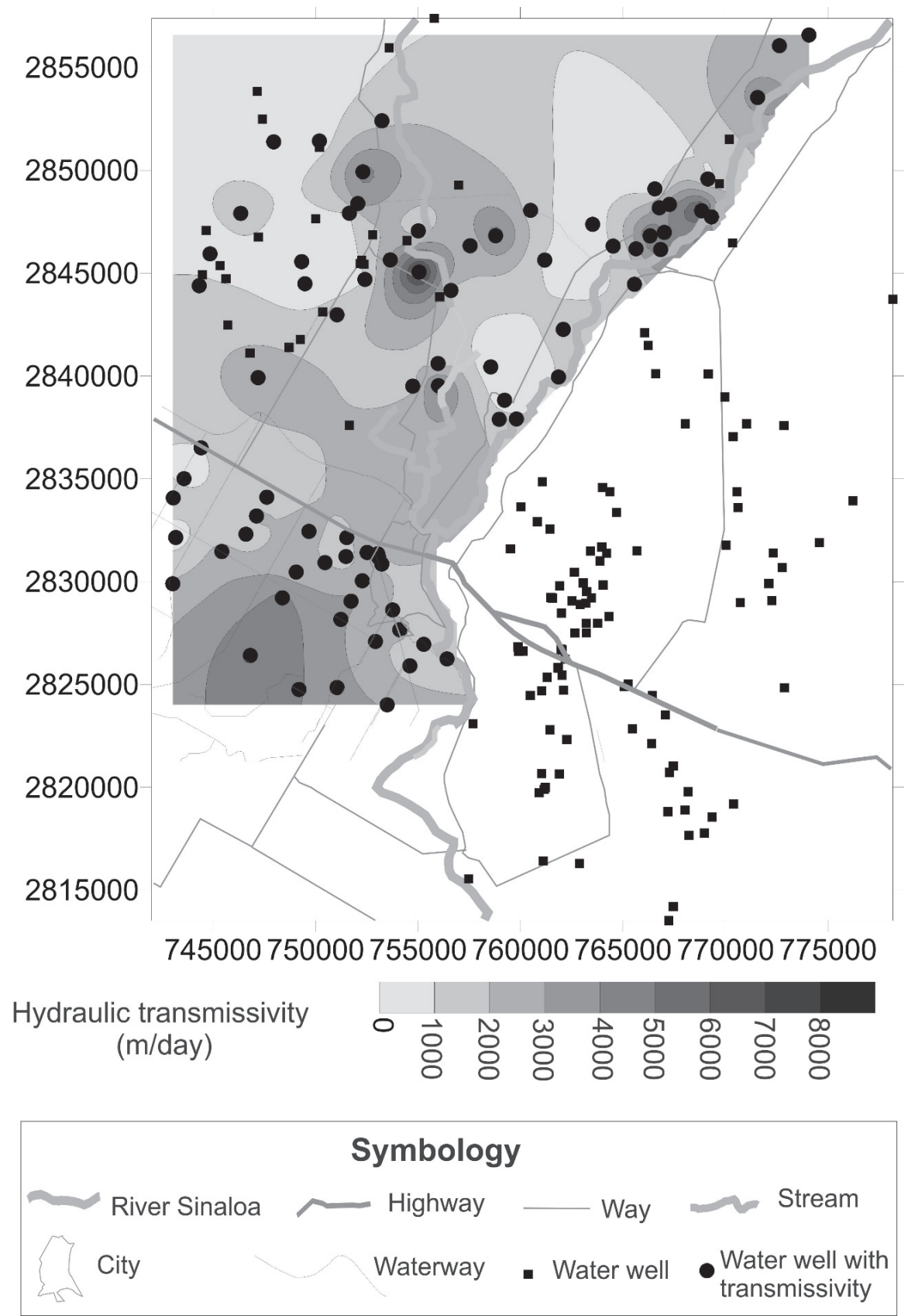

Figure 4. Transmissivity Isocontorms in $\mathrm{m}^{2} /$ day.

\section{DISCUSSION}

Specific capacity is directly proportional to $\mathrm{T}$, such as those obtained by [Ebong et al., 2014; Perdomo et al., 2014, Bosch, 2014, Zeferino et al., 2016, Hamm et al., 2005 y Galvão et al., 2016]. The relation $T / Q_{e}=$ 109.533 is in the range proposed by Bosch (2014) who established that the factor that relates $T$ with $Q_{e}$ oscillates in a range between 100 and 500 , reason why the relation obtained is consistent with that obtained in other aquifers, as reported by Perdomo et al. (2014) $\mathrm{T}=135.36 Q_{\mathrm{e}}$ - 50 and Zeferino et al. (2016) of $T=100.23 Q_{e}-7.126$ in different geological environments. In other studies, this relation has been of the exponential form as reported by Hamm et al. (2005) $T=0.99 Q_{e}^{0.89}$ where $\mathrm{T}$ and $\mathrm{Q}_{\mathrm{e}}$ are in $\mathrm{m}^{2} /$ day. Galvão et al. (2016) also proposes an empirical relationship in karst systems in Sete Lagoas, $M G$, Brazil. $T=330 Q_{e}{ }^{0.21}$ where $T$ and $Q_{e}$ are in $\mathrm{m}^{2} /$ day, the coefficient of determination $R^{2}$ was 0.55 . 


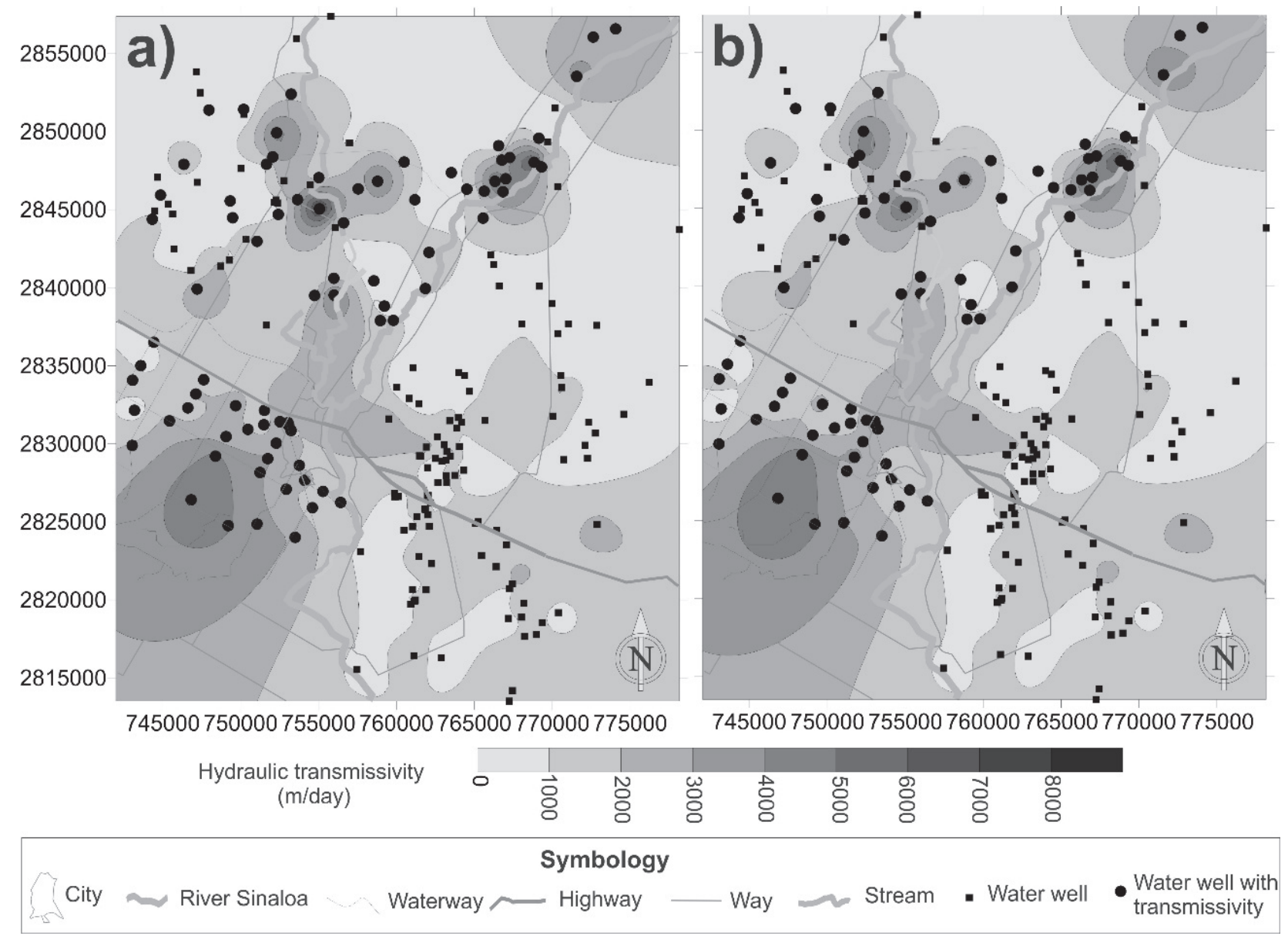

Figures 5a-b. Hydraulic transmissivity behavior ( $\mathrm{m}^{2} /$ day) in the study area: a) from the linear relation; b) from the Kalman filter application.

It has been found that the Kalman filter is a useful tool in the determination of the relation $T-Q_{\mathrm{e}}$, since it improved the relation between both parameters by increasing the correlation coefficient. The Thiem formula has a practical application that, although it is a relation for a homogeneous and isotropic medium, works in areas that present heterogeneities as is the present case.

Heterogeneities that are considered to have an effect with normal behavior in the T-Qe relation, which can be reduced by the Kalman filter, as indicated, the correlation increased from 0.95 to 0.97 .

The $T-Q_{e}$ relation has practical application since it allows to characterize the aquifer environment concerning $\mathrm{T}$.

\section{ACKNOWLEDGMENT}

Our gratitude to the General Direction of Research and Post graduate of the Autonomous University of Sinaloa for supporting the project and generate the suitable conditions to fulfill the present work.

\section{REFERENCES}

Al Farrah, N., M. Van Camp \& K. Walraevens. 2013. Deducing transmissivity from specific capacity in the heterogeneous upper aquifer system of Jifarah Plain, NW-Libya. Journal of African Earth Sciences 85: 12-21. DOI:10.1016/j.jafrearsci.2013.04.004

AsFAHANI, J. 2016. Hydraulic parameters estimation by using an approach based on vertical electrical soundings (VES) in the semi-arid Khanasser valley region, Syria. Journal of African Earth Sciences 117: 196-206.

Batenl, S. M., M. Mortazavi-Naeinl, B. Atale-Ashtiani, D. S. Jeng \& R. KhanbilVARDI. 2015. Evaluation of methods for estimating aquifer hydraulic parameters. Applied Soft Computing 28: 541-549. D0l:10.1016/j. asoc.2014.12.022

Bosch, A. P. 2014. Nociones de hidrogeología para ambientólogos. Universidad Almería. $500 \mathrm{p}$.

Chandra, S., S. Ahmed, A. Ram \& B. Dewandel. 2008. Estimation of hard rock aquifers hydraulic conductivity from geoelectrical measurements: a 
theoretical development with field application. Journal of Hydrology 357 (3): 218-227. D0I:10.1016/j.jhydrol.2008.05.023

CONAGUA (Comisión Nacional del Agua). 2000. Expediente técnico justificativo del acuífero del Río Sinaloa para la publicación de la disponibilidad en el Diario Oficial de la Federación. Culiacán, Sinaloa. 36 p.

Cruz-Falcón, A., J. Ramírez-Hernández, R. Vázquez-González, E. H. Nava-Sánchez, E. Troyo-Diéguez \& H. C. Fraga-Palomino. 2013. Estimación de la recarga y balance hidrológico del acuífero de la Paz, BCS, México. Universidad y Ciencia 29 (1): 87-100.

Ebong, E. D., A. E. Akpan \& A. A. Onwuegbuche. 2014. Estimation of geohydraulic parameters from fractured shales and sandstone aquifers of Abi (Nigeria) using electrical resistivity and hydrogeologic measurements. Journal of African Earth Sciences 96: 99-109. DOI:10.1016/j.jafrearsci.2014.03.026

EL-NAQA, A. 1994. Estimation of transmissivity from specific capacity data in fractured carbonate rock aquifer, central Jordan. Environmental Geology 23 (1): 73-80. D0I:10.1007/BF00773142

Faragher, R. 2012. Understanding the basis of the kalman filter via a simple and intuitive derivation [lecture notes]. IEEE Signal processing magazine 29 (5): 128-132.

Galvão, P., T. HalHan \& R. Hirata. 2016. The karst permeability scale effect of Sete Lagoas, MG, Brazil. Journal of Hydrology 532: 149-162. DOI:10.1016/j.jhydrol.2015.11.026

Grewal-Mohinder, S. \& A. P. Andrews. 1995. Kalman filtering theory and practice. Prentice Hall. $382 \mathrm{p}$.

Hamm, S. Y., J. Y. Cheong, S. Jang, C. Y. Jung \& B. S. Kim. 2005. Relationship between transmissivity and specific capacity in the volcanic aquifers of Jeju Island, Korea. Journal of Hydrology 310 (1): 111-121. D0l:10.1016/j.jhydrol.2004.12.006

INEGI (Instituto Nacional de Estadistica y Geografía). 2009. Prontuario de información geográfica municipal de los Estados Unidos Mexicanos, Sinaloa, Sinaloa. $9 \mathrm{p}$.

INEGI (Instituto Nacional de Estadística y Geografía). 2014. Anuario estadístico y geográfico de Sinaloa 2014. Instituto Nacional de Estadística y Geografía. México. 451 p.

Kazakis, N., G. Vargemezis \& K. S. Voudouris. 2016. Estimation of hydraulic parameters in a complex porous aquifer system using geoelectrical methods. Science of the Total Environment 550: 742-750. D0I:10.1016/j.scitotenv.2016.01.133

KIM, P. 2011. Kalman Filter for Beginners with Matlab Examples. CreateSpace Independent Publishing Platform.

MaLík, P., R. ČERnÁK \& J. ŠvaSTA. 2015. Comparison of Resistive Hydraulic Properties of Granitoids, Metamorphic and Carbonate Rocks from Specific Discharge Data. Engineering Geology for Society and Territory. Springer, Cham 3: 549-556. D0I:10.1007/978-3-319-090542_111
Norzagaray-Campos, M. 2003. Flujo regional en acuíferos, sus causas y efectos en la dispersividad hidrodinámica: un caso de estudio. Tesis doctoral, CINVESTAV-Unidad Mérida. Mérida, México. 169 p.

Painter, S. L., A. D. Woodbury \& Y. Jiang. 2007. Transmissivity estimation for highly heterogeneous aquifers: comparison of three methods applied to the Edwards Aquifer, Texas, USA. Hydrogeology Journal 15 (2): 315-331. DOI:10.1007/s10040-006-0071-y

Palafox-Ávila, G. 2006. Riesgo Potencial a inundaciones en la ciudad de Guasave, Sinaloa, México, Tesis de Maestría, CIIDIR-IPN Unidad Sinaloa. Guasave, Sinaloa. $115 \mathrm{p}$.

Peinado-Guevara, H. J., J. Herrera-Barrientos, 0. Delgado-Rodríguez, V. M. Peinado-Guevara, 0. Llanes-Cárdenas \& M. Ladrón de Guevara-Torres. 2017. Estimation of Hydrological Parameters from Geoelectrical Measurements. In: El Shahat, A (ed.). Electrical Resistivity and Conductivity. Intech Open, pp. 83-94. D0I:10.5772/67990

Perdomo, S. J., E. Ainchil \& E. Kruse. 2014. Hydraulic parameters estimation from well logging resistivity and geoelectrical measurements. Journal of Applied Geophysics 105: 50-58. D0I:10.1016/j.jappgeo.2014.02.020

Sánchez, Y. S., C. De Miguel-Fernández \& S. Rochenel. 2013. Caracterización hidrogeológica del Valle del Cauto, provincia Holguín, Cuba. Minería y Geología 29 (2): 16-34.

Sanz, D. S., J. Castaño-Castaño, J. Gómez-Alday \& P. E. Martínez-Alfaro. 2005. Magnitud y rango de transmisividades en las unidades acuíferas carbonatadas UH7 y UH2 del Sistema Mancha Oriental (SM0). SE Español. Geogaceta 39: 119-122.

TIzRo, A. T., K. Voudouris \& Y. BASAMI. 2012. Estimation of porosity and specific yield by application of geoelectrical method-A case study in western Iran. Journal of hydrology 454: 160-172. D0I:10.1016/j. jhydrol.2012.06.009

VarGAS, A. G. 2016. Influencia del sismo de Golfito del 30 de julio de 2002 (Mw 6, 2) sobre una prueba de bombeo en el acuífero confinado del sitio de presa del PH Pirrís, Costa Rica. Revista Geológica de América Central 54: 143-153. D0l:10.15517/rgac.v54i0.21151

Villanueva, M. \& A. Iglesias. 1984. Pozos y acuíferos. Madrid, España, Ibergesa. $426 \mathrm{p}$.

WRI (Water Resources Investigations 87-4034). 2008. Hydrogeology, Aquifer Characteristics, and Ground-Water Flow of the Surficial Aquifer System, Broward County. County, Florida. U.S. Geological Survey. 92 p. Also available at: sofia.usgs.gov/publications/wri/87-4034/ spcapacity.html.

Zeferino, J. F. C. 2016. Modelação numérica (FEFLOW) e contaminação por intrusão salina do sistema aquífero Mio-Pliocénico do Tejo, na frente ribeirinha do Barreiro. Tesis de Maestria, Universidad Nova de Lisboa, Portugal. 82 p. 